\title{
TRANSATLANTIC CONTEXT FOR GAELIC LANGUAGE REVITALISATION
}

\author{
STUART S. DUNMORE
}

University of Sussex / University of Edinburgh

\begin{abstract}
The notion of the 'new speaker', and its salience particularly in relation to minority language sociolinguistics, has become increasingly prevalent in the last decade. The term refers to individuals who have acquired an additional language to high levels of oracy and make frequent use of it in the course of their lives. Language advocates in both Scotland and Nova Scotia emphasise the crucial role of new speakers in maintaining Gaelic on both sides of the Atlantic. As a result, Gaelic language teaching has been prioritised by policymakers as a mechanism for revitalising the language in both polities. This article examines reflexes of this policy in each country, contrasting the ongoing fragility of Gaelic communities with new speaker discourses around heritage, identity, and language learning motivations. Crucially, I argue that challenging sociodemographic circumstances in Gaelic communities in Scotland and Nova Scotia contrast with current policy discourses, and with new speaker motivations for acquiring higher levels of Gaelic oracy in North America.
\end{abstract}

Keywords: language ideology; revitalisation; diaspora; heritage; motivation

\section{Introduction}

This article examines processes of Gaelic language revitalisation in three interconnected but ethnoculturally disparate settings. Gaelic is currently undergoing revitalisation on both sides of the Atlantic, and its speaker community thus represents an unparalleled context to evaluate policy outcomes in respect of a single minority language in contrasting geolinguistic and sociocultural settings. Language shift, loss, and revitalisation are matters of increasingly urgent institutional attention internationally (Nettle \& Romaine 2000; Romaine 2000, 2008, 2013; Fishman \& García 2010, 2011). Strategic attempts to retard the decline of minoritised languages internationally have increasingly focussed on 
the generation of 'new' speakers via second language acquisition - including 'revitalisation immersion education' (García 2009) - as a means to increase numbers of endangered language users (see also Williams, forthcoming).

This development, observed in various Indigenous contexts in Oceania, North and South America, as well as among national minorities in Western Europe generally, and throughout the Celtic-speaking world specifically, reflects a recognition by policymakers that once interrupted, intergenerational transmission of languages in the home domain is extremely hard to re-instate. The creation of 'new' speakers by other means has thus become increasingly important in the eyes of policymakers (see Williams, forthcoming), whilst that term has become increasingly prevalent in the sociolinguistics of European minority languages (O’Rourke \& Ramallo 2013; Hornsby 2015; O’Rourke, Pujolar \& Ramallo 2015; Smith-Christmas et al. 2018; Williams, forthcoming).

Unusually for an endangered minority language, new speakers of Gaelic have become a crucial demographic for language maintenance efforts on both sides of the Atlantic. In Scotland, Gaelic-medium education (GME) is a core focus of policymakers' strategies to revitalise Gaelic. In Nova Scotia, meanwhile, revitalisation efforts have tended to focus on language acquisition and socialisation outside of the formal domain of education, though the establishment in September 2021 of North America's first Gaelic immersion school, Taigh Sgoile na Drochaide in Mabou, Cape Breton marks an historic juncture for language policy in the province.

Policymakers in administrations in both Scotland and Nova Scotia thus look to new speakers as a basis for ensuring linguistic sustainability (Bòrd na Gàidhlig 2014, 2018; Nova Scotia Office of Gaelic Affairs 2018; Scottish Government 2014, 2021). One objective of the wider project this article outlines has been to assess the language learning and life experiences that inform Scottish and Nova Scotian new speakers' decision to learn and use Gaelic, and, relatedly, their cultural identifications with the language.

2. Revitalisation processes, ethnolinguistic identities and second language acquisition

Fishman (1991: 406) emphasised the importance of securing minority varieties as languages of home-community life - and communities' failure to retain minority language use in this functional sphere having contributed to the failure of various revitalisation initiatives. Fishman (1991, 2001a, b, 2010, 2013) consistently argued that school-based language policy interventions would ultimately fail unless efforts were directed at acquiring space for habitual use of minority varieties outside of classrooms (Fishman 2001b: 471; cf. Edwards 2010: 261; Baker 2011: 265). 
It may be argued, however, that Fishman's (1991, 2001a, b, 2013) model and recommendations drew on a conception of language and ethnic identity which many contemporary sociolinguists would regard as problematic. In particular, the feasibility (either theoretical or practical) of a straightforward relationship between a given minority language ('Xish') and its ethnolinguistic community ('Xmen/Xians') has been critiqued by various authors (cf. Edwards 2010; Heller 2006, 2010; Romaine 2006, 2013; Jaffe 2007a, b). In short, contemporary anthropologists and (socio)linguists tend to distance themselves from essentialist positions which view members of a given identity category to be "both fundamentally similar to one another and fundamentally different to members of other groups" (Bucholtz \& Hall 2004: 374). Fishman's (1991: 394) model rests to a large degree upon the proviso that "Xmen are not Ymen and that Xish culture [...] is not Yish culture", an equation that betrays a distinctive and influential linguistic ideology (after Silverstein 1979: 193).

Research conducted over the last three decades in particular has shown that language ideologies are frequently advanced in speakers' discourses as attempted rationalisations for language practices (Kroskrity 2000, 2004; Bucholtz \& Hall 2004; García 2009; Makihara 2010). Another particularly relevant perspective on questions of language and group identity is reflected in Gardner and Lambert's (1959, 1972) 'integrativeness' model. Based on detailed and longstanding research on French-English bilingualism in Canada, Gardner and Lambert (1959, 1972) hypothesised that integrative motivation reflected genuine desire on the part of second language learners to integrate with the L2 community. Integrativeness in that context (and many others subsequently) was seen to significantly influence successful L2 acquisition (see Rosiak, forthcoming). Yet, clearly, this model's applicability to the context of heritage language learning in Scotland and Canada may be limited in relation to Gaelic, which, whilst frequently conceived on the one hand as a 'national' language of Scotland, is also sometimes regarded as a more circumscribed or regional ethnolect (Oliver 2005, 2006).

Dörnyei (2005) and Ushioda (2011; Dörnyei \& Ushioda 2009) refined the concept of the 'motivational self-system', which views second language learners' acquisition of an additional language to be guided largely by imagined identities or 'selves' in the L2. Crucially for the present article, MacIntyre et al. (2017) conceptualised Nova Scotian Gaelic learners' motivations in terms of the 'rooted L2 self', distinguishing the heritage orientations of Gaelic learners from L2 learner motivations in contexts where such identifications with target varieties tend not to be found (cf. Rosiak, forthcoming). 


\section{Socio-historical context: Gaelic in Scotland and Nova Scotia, Canada}

\subsection{Alba / Scotland}

As the Scots or Gaels extended their political and cultural influence over the mainland of northern Britain $(A l b a)$ from around $500 \mathrm{CE}$, their language expanded over the vast majority of what became Scotland (Dumville 2002; Ó Baoill 2010; Clancy 2011). From the early twelfth century, as the social structures of the Gaelic kingdom of Alba were replaced by those of an Anglo-Norman nobility, vernacular use of Gaelic became gradually but inexorably restricted to the Highlands and Hebridean islands (Barrow 1989). After the16th century Scottish reformation, hostility to Gaelic on the part of the Scots state became connected to policy to remove impediments to the consolidation of state power. Anti-Gaelic policies were adopted throughout the $17^{\text {th }}$ century as part of an early wave of sociocultural 'improvement' (Withers 1984), a process which accelerated in the aftermath of the 18th century Jacobite rebellions. Ultimately this longstanding dynamic culminated, during the 19th century, in landowning classes' implementation of policies of mass displacement that subsequently became known as the Clearances (Withers 1984; Glaser 2007; Richards 2007). As Gaels were increasingly compelled to assimilate to Lowland, Anglophone norms or emigrate, the minoritisation of Gaelic hastened rapidly.

57,600 people were reported able to speak Gaelic in Scotland in the 2011 census, or around $1.1 \%$ of the Scottish population (National Records of Scotland 2013). This census return also showed growth, for the first time, in the proportion of Gaelic speakers under the age of 20 (cf. Bòrd na Gàidhlig 2014; 2018; Scottish Government 2014) and new speakers of various language learning backgrounds have become an increasingly important demographic in Gaelic communities. Studies of new Gaelic speakers by McLeod et al. (2014) Nance (2015) and Nance at al. (2016) emphasised interviewees' association with the term 'Gaelic community'/Coimhearsnachd na Gàidhlig in preference to the ethnonym 'Gaels/Gàidheil' (cf. Oliver 2005, 2006).

The significance of new speakers in the Scottish context becomes clear when we examine specific language policies and political discourses. Bòrd na Gàidhlig, the arms-length public body with statutory responsibility for promoting Gaelic, and for preparing a National Gaelic Language Plan (NGLP) every 5 years under the Gaelic Language (Scotland) Act 2005, stated the following in the most recent iteration of its NGLP:

Gaelic education is central to the ambition of Gaelic growth and for this reason education and learning will remain central to this Plan, as they were to the previous Plan... Our clear view is that Gaelic education makes an important contribution to 
the aim of increasing the numbers of those speaking, using and learning the language. (Bòrd na Gàidhlig 2018: 32)

The Scottish Government, which ultimately has recourse under the 2005 Act to legally enforce Bòrd na Gàidhlig's policies, has similarly stressed the importance of Gaelic education as a means to create greater numbers of new speakers. The Scottish National Party's recent manifesto, published before that party was reelected in May 2021 as the governing party in the Scottish Parliament, stated:

[W] e remain committed to ensuring [Gaelic] has a sustainable long-term future. In particular we will have a focus on arresting the intensifying language shift in the remaining vernacular communities. Gaelic Medium Education (GME) is a key driver for ensuring that Gaelic continues to thrive and grow in both urban and rural areas. (Scottish National Party 2021: 65)

Thus the relevance of new speakers is rather implicit in both foregoing statements of language policy; there is tacit understanding on the part of Scottish policymakers that Gaelic education, and immersion education (GME) in particular, has the potential to create committed new speakers of the language. In turn, it is hoped that sustainable numbers of these speakers will subsequently have both the ability and inclination to become frequent users of Gaelic, to pass it on to their own children in future, and thereby contribute to arresting the ongoing (and "intensifying") language shift in the remaining "vernacular communities" (Ó Giollagáin et al. 2020; Scottish National Party 2021). This term has recently been utilised by Ó Giollagáin et al. (2020) to refer to the vestigial social geography of a small number neighbourhoods in the Western Isles, Skye and Tiree where least a nominal majority of local inhabitants retain speaking ability in Gaelic as an L1. Rapidly declining levels of Gaelic oracy even in areas such as this are a continuing cause for concern, as reflected in the SNP manifesto extract cited above (Scottish National Party 2021).

\subsection{Alba Nuadh / Nova Scotia}

The name Nova Scotia ('New Scotland') was first coined in reference to the lands of the Indigenous Mi' kmaq people in 1621, when they were chartered to William Alexander, first Earl of Stirling for colonisation (Campbell \& MacLean 1974: 35; Mertz 1982: 36). The first Gaels to immigrate en masse arrived in 1629, and while Alexander's attempts to establish a sizeable Scottish colony were initially unsuccessful, Highlanders continued to migrate in small numbers during the $17^{\text {th }}$ and early-18 $8^{\text {th }}$ centuries (Ó hIfearnáin 2002: 64). Migration accelerated in earnest from the 1770s, as the middle class Gaelic 'tacksmen' sought a new life in North 
America as a response to declining prospects at home. By the 1840 s most Highland migrants comprised the displaced and homeless tenant classes left destitute as a result of the Clearances.

Between these decades over 50,000 Highland Scots are estimated to have arrived into eastern counties of Nova Scotia and Cape Breton island (MacKinnon 2001: 20; Kennedy 2002: 20-21; Ó hIfearnáin 2002: 65). Kennedy (2002: 277) observes that within in these districts a "truly Canadian and North American Gaelic community" developed and flourished in the $19^{\text {th }}$ century. Yet, he also states that children of Gaelic speakers learned next to nothing of their language in schools after state education began, and that they internalised negative attitudes regarding the relative unimportance of Gaelic in Anglophone Canadian society as a result (Kennedy 2002: 51; cf. Edwards 2010: 156-7).

Cape Breton's Gaelic population had declined to just 24,000 by the 1931 census (MacKinnon 2001: 19) and recorded Gaelic speakers in Nova Scotia generally continued to decline by around $50 \%$ in each subsequent census return of the $20^{\text {th }}$ century (ibid; cf. MacLean 1978). Mertz's $(1982,1989)$ detailed research on language shift in the province identified the key "metapragmatic filter" through which Nova Scotia Gaels came to attribute relative values to their languages during this period. The 1920s and 30s transformed prevailing socioeconomic circumstances in Nova Scotia, enhancing the ideological association of Gaelic with rurality, immobility and limited prospects. Mertz (1982: 311-2) observed that the language ideologies around Gaelic that had the greatest consequence for its future use were those that prevailed at the time of the Great Depression. As Gaelic approached its linguistic tip in Nova Scotia, language shift to English accelerated and Gaelic speakers migrated in large numbers to urban centres in Halifax, Ontario and New England (especially Boston; Kennedy 2002: 73; Edwards 2010: 154).

The 2011 Canadian census recorded 1,275 speakers of 'Gaelic languages' in Nova Scotia, amounting to just over $0.1 \%$ of the provincial population (it is highly likely that the great majority of these are Scottish Gaelic speakers, though some may be Irish or Manx speakers; Statistics Canada 2015). Of that number, only 300 individuals reported Gaelic as their mother tongue (Statistics Canada 2017) with the majority having instead acquired Gaelic languages in adolescence or adulthood. These rather unwieldy census data broadly demonstrate the increasing importance of new speaker networks relative to declining native Gaelic communities in the province. Language policy to revitalise Gaelic in Nova Scotia can be traced to grassroots efforts that started in the 1970s, joined at the start of this century by increased institutional support for the language (Dunbar 2008; Edwards 2010).

In 2006, Premier Rodney MacDonald (now CEO of the Gaelic College in St Anns, Cape Breton) established Oifis Iomairtean na Gàidhlig (The Office of 
Gaelic Affairs) within the provincial civil service to support a ministerial portfolio for Gaelic Affairs. In spite of the small numbers of reported Gaelic speakers in Nova Scotia, the Office of Gaelic Affairs (2018) has estimated that at least 230,000 Nova Scotians claim descent from families who spoke Gaelic historically. As in Scotland, therefore, second language teaching has been prioritised by policymakers as a mechanism for revitalising Gaelic, and new speakers have emerged as a highly significant element within the Nova Scotia Gaelic community. Iomairtean na Gàidhlig exists, in its own words, for the purpose of assisting:

Nova Scotians [to] reclaim their Gaelic language and identity as a basis for cultural, spiritual, community and economic renewal [...] by creating awareness, working with partners and providing tools and opportunities to learn, share and experience Gaelic language and culture. (Office of Gaelic Affairs 2018).

While the emphasis here on language learning, tools and materials highlights the importance of new speakers to the future of Gaelic in the province, very little has previously been known about either the size or linguistic practices of the new speaker population (Watson and Ivey 2016: 184). The provincial government provides funding and support for the landmark Gàidhlig aig Baile ('Gaelic in the home') immersion and Bun is Bàrr ('Root and branch') master-apprentice programmes, both of which regularly emphasise the importance of ongoing interaction with remaining L1 and other fluent speakers for socialising new speakers in the language and developing their identities as Gaels (cf. MacEachen 2008).

Gaelic educational opportunities in Nova Scotia are limited by comparison with Scotland, where over 6000 children are currently enrolled in GME (Bòrd na Gàidhlig 2020: 6). Following the announcement of significant development funding from the provincial government, Nova Scotia's first Gaelic immersion school, Taigh Sgoile na Drochaide (Mabou/'The Bridge' School House) is slated to open in September 2021 as a private school operating outside of the formal education system in western Cape Breton. Elsewhere in the province, L2 Gaelic teaching tends to be limited to a small number of primary and secondary schools, residential immersion courses and university classes (MacEachen 2008; Dunbar 2008; Watson \& Ivey 2016). As will be demonstrated in the following analysis of interview extracts, an emphasis on ethnolinguistic identity and discourses of cultural distinctiveness tend to predominate in Nova Scotia's Gaelic community, closely paralleling recommendations advocated by Fishman. 


\section{Research design and methodology}

The interview data I draw on for the following analysis were collected over seven years of research in Scotland, and three months' ethnographic fieldwork in Nova Scotia. This wider study drew on 60 semi-structured interviews with new speakers of Gaelic (30 in each country), 4 focus groups ( 2 in each), 80 survey responses, and participation in Gaelic community life in the two countries (Dunmore, forthcoming). The analysis developed here will focus on four interview extracts. In Scotland, data were collected in Edinburgh, Skye, Glasgow and Inverness. In this context, seven of the 30 interviewees were educated through GME, while the remaining 23 acquired Gaelic to fluency later in life. 14 speakers were female, and 16 male, while ages ranged from 18 to 82 .

As discussed elsewhere (Dunmore 2017, 2019), Scottish new speakers' identifications with Gaelic language varied, but were never described in terms analogous to the 'Xians-with-Xish' ideal emphasised in Fishman's RLS model (1991, 2001b). In Nova Scotia, interviews were conducted from 2017 to 2018 in Halifax, Antigonish and throughout Cape Breton Island. Most participants had grown up in Cape Breton, and ranged in age from 17 to 73; 19 were female and 11 male. Nova Scotian interviewees' Gaelic learning trajectories and cultural identifications were notably different from those of most Scots participants; all 30 new speakers in Nova Scotia acquired their Gaelic principally through a combination of extracurricular community classes and immersion courses outside of school.

All 60 interviews were transcribed using Elan, and transcripts were coded thematically for the most salient categories of discourse that emerged. The analysis developed below employs an ethnography of speaking methodology, a central premise of which conceives of interaction in terms of the speech situation, event and act (Hymes 1974: 52). By focusing on these three levels of analysis, Hymes emphasised that language ought not to be separated from how it is used in practice (Saville-Troike 2003: 120). The following analysis foregrounds the notions or act sequences, keys, or context-based clues that may help to establish the "tone, manner, or spirit" in which a speech act is intended (Hymes 1974: 57), and linguistic "instrumentalities" or varieties that participants employ (Hymes 1974: 60). In the remainder of this paper I draw attention to the language ideologies that new speakers from both contexts convey when describing their identifications with Gaelic. A clear distinction will be demonstrated between Scottish new speakers' lack of association with the term 'Gael(s)', and their Canadian counterparts' use of the term. 


\section{Analysis: New Speakers of Gaelic and Conceptions of Gaels}

As with previous research on new Gaelic speakers in Scotland (cf. Oliver 2005, 2006; McLeod et al. 2014; Nance et al. 2016), a sense of detachment was generally conveyed by interviewees when discussing the term 'Gael'. In the first extract below, my interviewee rejects the label outright, partly as a consequence of her different experiences acquiring and using Irish in Ireland, and Gaelic in Scotland:

\section{Extract 1.}

SD A bheil fèin-aithne agad mar Ghàidheal?

Do you have an identity as a Gael?

GF01 Uh no absolutely not [...] is dòcha (1.2) gur e rud eachdraidheil a th' ann- bha na Gàidheil ann an Alba really (1.1) cut-off deliberately

Uh no absolutely not [...] perhaps (1.2) it's a historic thing- the Gaels in Scotland were really (1.1) cut-off deliberately

SD Hmm

GF01 Em:: and (1.2) bha iad (0.8) othered [...] like ann an Ėirinn cha robh mi a' faireachdain "oh yeah there's the Gaels and then there's us" ach tha mi faireachdainn sin 's dòcha ann an Alba

Em:: and (1.2) they were (0.8) othered [...] like in Ireland I never felt like "oh yeah there's the Gaels and then there's us" but I maybe do feel like that in Scotland

A sense of alienation from a distinctive ethnolinguistic Gaelic identity is clearly communicated in this extract, emphasised here in Hymes's (1974) terms, by keys to the speaker's sociopragmatic meaning, reflected in the use of hesitations, and frequent code-switching to English as an instrumentality to distance herself from the label 'Gael' (in the Scottish context, at least). This extract tends to reflect the wider experience of most new speakers of Gaelic in Scotland (see also McLeod et al 2014; Dunmore 2017, 2018, forthcoming). Whilst such a clear rejection of a social identity as Gaels is by no means uniformly expressed by all members of this group, the ethnolinguistic category is overwhelmingly avoided or problematized by most Scottish new speakers in my research. By contrast, most Nova Scotian new speakers' enthusiastically embrace the label 'Gael' when describing their motivations for having learned the language. In the following extract, my informant explains the varying ways in which contrasting Scottish and Gaelic identities are regarded in the province: 


\section{Extract 2.}

Bruidhinn orm fhìn cha robh- chanainnsa gu làidir a-nis gur e Gàidheal a th' annam- gur e bana-Ghàidheal a th' annam ach cha robh fios agam gu dè a bha ann an Gàidheal mun a thòisich mi air Gàidhlig ionnsachadh agus a-nis nuair a bhios mi coimhead air mo theaghlach tha fhios- ged nach eil Gàidhlig acasan tha mi faicinn cho Gàidhealach 's a tha iad sna dòighean aca (.) Agus mar sin chanainn gu bheil mòran ann an Alba Nuadh (.) a tha gu math Gàidhealach, ged nach eil Gàidhlig aca tuilleadh, bha Gàidhlig a's na teaghlaichean aca o chionn fhios agad - ginealach no dhà... ach cha bhiodh iadsan ag aithneachadh (.) uh: (.) ag aithneachadh (.) uh (.) an ainm 'Gàidheal' (.) you know chanadh iad dh'fhaoidte 'oh we're Scottish- we're Scotch'

Speaking about myself-I'd say now that I'm a Gael- that I'm a Gaelic woman but I didn't know what a Gael was before I started learning Gaelic and now when I look at my family I know - although they don't speak Gaelic - I can see just how Gaelic they are in their ways (.) And therefore I'd say lots of people in Nova Scotia are quite Gaelic, even though they can't speak Gaelic anymore, their families spoke Gaelic - you know a generation or two ago... But they wouldn't recognise uh the name 'Gael' you know, they'd maybe say 'oh we're Scottishwe're Scotch'

This extract highlights the speaker's changing awareness and appreciation of her Gaelic identity as her exposure to the language increased. On the other hand, she identifies the (extralinguistic) cultural practices of the people she was surrounded by whilst growing up as being stereotypically 'Gaelic' in various ways. She notes, however, that this sense of cultural distinctiveness was understood by such individuals as reflective of their 'Scottish' (or 'Scotch') heritage, rather than of any identity as 'Gaels'. This quality of cultural distinctiveness among Nova Scotians forms a frequently occurring trope across the 30 interviews conducted in the province. For the following interviewee, whose ancestry was predominantly Irish rather than Scottish, an orientation toward a pan-Gaelic ethnoculture - yet one rooted strongly in Atlantic Canada - is described:

\section{Extract 3.}

SD Tha ùidh shònraichte agam san fhacal Gàidheal (.) an e Gàidheal a th' annad?

I'm particularly interested in the term Gael (.) are you a Gael?

HALM1O tha mi cinnteach gur e- tha mi cinnteach gur e- 's ann o chionn dà: che:ud bliadhna a thàinig mo mhuinntir an-seo

Oh sure I am-I'm sure I am- my people came here two:

h:undred years ago 


\section{SD Yeah}

HALM1 Ach 's e Gàidheil a th' ann- 's e Gàidheil a th' annta [...] 's ann à Contae Lough a bha iad (.) uh m' athair agus mo mhàthair 's ann à Contae uh Port- Phort Lairge [...] ach 's ann à New Brunswick a tha mo mhuinntir

But they were Gaels- they're Gaels [...] they were from (.) County Louth (.) uh [on] my father's [side] and on my mother's- County Wat- Waterford [...] but my people are from New Brunswick

This sense of association with a wider, common Goidelic community stands in stark contrast, as previously noted, to the majority of new speakers in Scotland (or indeed Ireland; see O'Rourke \& Walsh 2020) even for those, as in extract 1, with direct family ties to Ireland and the Irish-speaking community. The focus on ancestry conveyed in the above extract is therefore somewhat different to the Highland Gaelic connection emphasised by most Nova Scotia Gaels. Yet for the following speaker, a sense of identity as a Gael is problematised, and the necessity of possessing such an ancestral connection is questioned and critiqued. In this way the interviewee avoids excessively relying, in her own words, on 'purism' in discussing her relationship to the Gaelic language, a tendency that she observes can sometimes occur too frequently in Nova Scotia's Gaelic community:

\section{Extract 4.}

SD: Bheil thu coimhead ort fhèin mar bhana-Ghàidheal?

Do you regard yourself as a Gael?

CBIF9: Uh huh (.)^uill [[ann an ^ dòigh]

$\wedge^{\wedge}$ well [[in $a^{\wedge} \underline{\text { way }]}$

SD: [[An canadh tu sin?] [[Would you say so?]

CBIF9:Ann an dòigh [...] ach tha cuimhne agam nuair a bha mi aig an t-Sabhal Mhòr bhiomaid daonnan a-mach air a' chuspair seo

In a way [...] but I remember when I was at Sabhal Mòr [Ostaig;

Gaelic College on the Isle of Skye] we were always discussing that issue

SD: Yeah

CBIF9: Agus uaireannan bhithinn ag ràdh (.) 'carson?'[...] Bidh mi ag ràdh gur $\mathrm{e}($.$) bana-Ghàidheal a th' annam [. .$.$] tha e gu { }^{\wedge}$ math cudromach an-seotha sinn a' feuchainn a bhith cleachdadh an fhacail siud- Gàidheal And sometimes I would ask (.) 'why?' [...] I do say I am a Gael [...] it's ^quite important here-we try to use that word-Gael

SD: $\mathrm{Hmm}$ 
CBIF9: Uh (.) o tha e air atharrachadh tro na linntean Oh but it's changed over the years

SD: $\quad$ Sheadh

Yeah

CBIF9: Bho- you know- 'Highlander' [[no 'Scots']

SD: [[Highlander yeah] From- you know- 'Highlander' [[or 'Scots']

CBIF9: 'Scottish', 'Celtic'- diofar- diofar rudan [...] tha mi faireachdainn gu bheil um (1.4) tha:: hh: tha (.) tha sinn a' siubhail tro ^purism an-seo $\wedge$ uaireannan (.) agus uaireannan chan eil sin a' còrdadh rium 'Scottish', 'Celtic' - different- different things [...] I feel that um (1.4) there's:: hh:: that (.) we rely too much on ^purism here ^sometimes (.) and sometimes I don't enjoy that

In the above extract, the speaker therefore qualifies her assertion of identity as a Gael with the phrase 'in a way' (ann an dòigh), producing rising intonation and heavy emphasis on the final word to convey this stance clearly. These paralinguistic keys in her speech - and her later reference to excessive 'purism' in the local Gaelic community - indicate the interviewee's sense that her ownership of this identity may be seen as problematic. She recounts a sense of disillusionment at how prevalent discussion of the term 'Gael' seemed to her when studying at Sabhal Mòr Ostaig on the Isle of Skye. Yet the interviewee goes on to explain that she does in fact describe herself as a Gael ('bidh mi ag ràdh gur e bana-Ghàidheal a th' annam') noting that Nova Scotian speakers consciously attempt to use the term. The participant's somewhat hesitant allusion to 'purism' at the end of extract 4, in relation to attempts to popularise the identity of the 'Gael' via heritage and ancestry is particularly noteworthy.

\section{Discussion: Gaelic in contemporary Scotland, Nova Scotia and New} England

The preceding analysis has attempted to demonstrate that whilst a straightforward linkage between language and ethnolinguistic identity, as theorised in Fishman's RLS model (1991, 2001b, 2013) fails to materialise amongst new Gaelic speakers in Scotland, it is frequently reported and conveyed in interviews conducted in Nova Scotia. A relative lack of identification with the label 'Gael' among new speakers in the context of GME, first documented two decades ago by Oliver $(2002,2005,2006)$ has important implications for the applicability of Fishman's model in Scotland. In my research, the 'Xian' ethnolinguistic community referenced by the term 'Gael(s)' is not one with which Scottish new speakers tend to associate, or with which they would wish to integrate as part of their ideal or 
'rooted' L2 selves (cf. MacIntyre et al. 2017; Dunmore 2019, 2021, forthcoming).

The relative enthusiasm with which Nova Scotian new speakers of Gaelic embrace and negotiate their identities as Gaels thus stands in stark distinction to Scottish speakers' relationship with the term. I suggest that on the one hand, a heightened awareness among new speakers in Scotland of ongoing community decline in heartland areas (cf. Ó Giollagáin et al. 2020) appears to undermine a sense of identification with the community of Gaels who persist there. In Nova Scotia, by contrast, the Gaelic 'community' now exists almost entirely as a network of L2 speakers since the L1 group is now at the point of virtual disappearance (albeit various new speakers are now raising children with Gaelic as an L1).

Whilst the practicability of positing a straightforward relationship between minority languages and their speakers as a strategy for revitalisation has been problematised by authors such as Jaffe (1999, 2007a, b), Edwards (2010, 2013), and Duchêne and Heller (2007, 2012), Nova Scotian new speakers' clear desire to embrace an identity as Gaels closely parallels Fishmanian conceptions of the language-identity nexus. Such models of language and ethnic identity clearly sit uneasily with contemporary critiques of essentialist perspectives in social research (Jaffe 1999, 2007a) yet, as Bucholtz and Hall (2004:376) argue, essentialist perspectives often continue to possess meaning and value for the speakers whom linguists study. In that sense, Bourdieu's (1991: 221) point that we may only understand the nature of social reality by including in our examinations "the representation of reality" seems well made. At the same time, Dorian (2010: 89) cautioned on the basis of her longstanding ethnography of East Sutherland Gaelic that the situated and context-bound relationship of language to identity is rarely as straightforward as essentialist conceptions would envisage.

Amongst Nova Scotian new Gaelic speakers, therefore, ethnolinguistic identities are often constructed in a way that critical analysts may regard as essentialist. Yet they do so within a wider North American context in which perceived ethnic heritage often does form the basis of cultural identity claims. A crucial objective of my forthcoming research scholarship at Harvard University will be to examine in depth the social construction of heritage and ethnolinguistic identity among Gaelic learners and new speakers in New England. As a destination for secondary Gaelic migration from Nova Scotia since the $19^{\text {th }}$ century, what role is the language regarded to fulfil in speakers' social reality, and what motivates their quest to attain higher levels of Gaelic oracy, far from the traditional heartlands of Cape Breton or the Scottish Highlands? Lastly, what relationship to the better-known Boston Irish diaspora to Scottish Gaelic learners and speakers in this context possess?

In Scotland, new Gaelic speakers' principal identification with the language often derives from their educational and professional lives (cf. McEwan-Fujita 
2008, 2020). Yet without strong sociocultural identities in the language outside such formal spheres, it would seem naive to expect large numbers of new speakers to make the language a vital aspect of their home and family lives, or to transmit it to children in future. Conversely, whilst Nova Scotian new speakers may well possess the necessary ideological and ethnolinguistic commitment for raising children with Gaelic, the relative paucity of formal acquisition opportunities - and the fast-dwindling community of L1 speakers - provide clear challenges for the socialisation of young people in the language itself.

If greater numbers of new Gaelic speakers are to be created, who will use the language in the home-community sphere as an aspect of their social reality and cultural identity, additional resources should be focused on that specific objective in Scotland, as is already the case in Nova Scotia. If sustainable numbers of new Gaelic speakers are to be generated in the province, however, it is clear that discourses privileging ancestry for embracing and acquiring Gaelic (the 'purism' alluded to in extract 4, above) should be avoided. More civic views of Gaelic as a language and identity that is open to all peoples of Nova Scotia may find a wider, more receptive audience in the province.

Finally, whilst Nova Scotian Gaelic speakers seek to build on the relative success of Scottish GME with the establishment of the province's first Gaelic immersion school, teachers and advocates in Halifax, Antigonish and Cape Breton should be encouraged to be mindful of that system's shortcomings in the 'old country' and to exploit their own community's strengths to foster an inclusive but distinctive curriculum (Dunmore 2017, 2019). Scottish children currently in GME schools and classes should clearly be encouraged to use and socialise in the language outside of the formal domain of education as much as possible, to interact with remaining native speakers, and to understand the importance of Gaelic, both to their civic identities as Scots and as budding Gaelic speakers in a multicultural Scotland (see Dunmore 2017, 2018, 2019).

\section{Conclusion}

The data presented in this article reveal likely outcomes of current language revitalisation processes in Scotland and Nova Scotia. In Scotland, most new speakers reject the label 'Gael' as an emic desciptor of their own identities. These new Gaelic speakers' lack of identification as Gaels is not problematic for language policy objectives as such, but functional fluency does not appear often to be accompanied by a strong social identity in Gaelic. If strong and supportive cultural identities in Gaelic are among the intended outcomes of GME, in the sense that they may bolster future language use, additional resources should be directed specifically at this objective. As I have argued elsewhere (Dunmore 2019), encouraging current students' development of linguistic ideologies and 
identities that will contribute to their future use of the language - wherever they live in Scotland - may make a substantive difference to future long-term outcomes of GME.

In Nova Scotia, by contrast, the ethnolinguistic component of new speakers' Gaelic language socialisation appears to be effectively developed amongst most learners. Whilst heritage and ancestry often appear from interviewees' own accounts to form the principal motivation for acquiring and using Gaelic in their daily lives, specific emphases on lineage and descent could be alienating for other ethnolinguistic groups in Nova Scotia who might otherwise engage with Gaelic. The clear contrast between the two settings reflects the divergent histories and social realities of Gaelic communities in Scotland and North America, of which greater numbers of new speakers are increasingly an important part. It is clear, however, that language advocates and policymakers on both sides of the Atlantic have much to learn from one another.

\section{Acknowledgements}

The research discussed in this article was generously funded by a British Academy Postdoctoral Fellowship held at the University of Edinburgh from 2016 to 2019. I am obliged to the Royal Society of Edinburgh for sponsoring my forthcoming Fulbright visiting scholar appointment at Harvard University. I am also particularly grateful to Prof. Hornsby for inviting me to deliver a talk at the Adam Mickiewicz University Irish Studies seminars, on which this paper is based, and to the Government of Ireland / Irish Embassy in Warsaw for sponsoring that series.

Key to transcription conventions

\begin{tabular}{|c|c|}
\hline [words] & overlapping speech \\
\hline$()$. & perceivable pause <1s duration \\
\hline$(2.0)$ & perceivable pause >1s duration \\
\hline$($ word $)$ & uncertain transcription \\
\hline$(\mathrm{x})$ & unintelligible \\
\hline$(($ word) $)$ & analyst's comments \\
\hline$[\ldots]$ & material omitted \\
\hline wo:: & elongation \\
\hline word & emphatic speech \\
\hline word= & latched speech, no pause \\
\hline words & codeswitch \\
\hline
\end{tabular}




\section{REFERENCES}

Baker, Colin. 2011. Foundations of bilingual education and bilingualism, 5th edn. Bristol: Multilingual Matters.

Barrow, Geoffrey W. S. 1989. The lost Gàidhealtachd of medieval Scotland. In William Gillies (ed.) Scotland and Gaelic/Alba agus a' Ghàidhlig, 67-88. Edinburgh: Edinburgh University Press.

Bòrd na Gàidhlig. 2014. Gaelic Education Helps Reverse Decline of the Gaelic Language. http://www.gaidhlig.org.uk/bord/en/news/article.php?ID=474 (accessed 09.07.2019).

Bòrd na Gàidhlig. 2018. National Gaelic language plan, 2018-2023. Inverness: Bòrd na Gàidhlig.

Bòrd na Gàidhlig. 2020. Gaelic School Data. <https://www.gaidhlig.scot/wpcontent/uploads/2020/11/D\%C3\%A0ta-Sgoile-POBLACH-2019-20-2.0-BnGPUBLIC-Schools-Data.pdf> (accessed 19.07.2021).

Bourdieu, Pierre. 1991. Language and Symbolic Power. Transl. G. Raymond \& M. Adamson. Cambridge: Polity Press.

Bucholtz, Mary \& Kira Hall. 2004. Language and identity. In Alexander Duranti (ed.) A companion to linguistic anthropology, 369-94. Oxford: Blackwell.

Campbell, Donald \& R. MacLean. 1974. Beyond the Atlantic roar: A study of the Nova Scotia Scots. Toronto: McClelland \& Stewart.

Clancy, Thomas O. 2011. Gaelic in medieval Scotland: Advent and expansion. Proceedings of the British Academy 167:349-92.

Dorian, Nancy. 2010. Linguistic and ethnographic fieldwork. In Joshua A. Fishman \& Ofelia García (eds.), Handbook of language and ethnic identity: Disciplinary and regional perspectives (Vol. I) $2^{\text {nd }}$ edn, 89-106. Oxford: Oxford University Press.

Dörnyei, Zoltán. 2005. The psychology of the language learner: Individual differences insecond language acquisition, Mahwah, NJ: Lawrence Erlbaum.

Dörnyei, Zoltán, \& Ema Ushioda (eds.). 2009. Motivation, language identity and the L2 self. Bristol: Multilingual Matters.

Duchêne, Alexandre \& Monica Heller (eds.). 2007. Discourses of endangerment: Ideology and interest in the defence of languages. London: Continuum.

Duchêne, Alexandre \& Monica Heller. 2012. Language in late capitalism: Pride and profit. London: Routledge.

Dunbar, Rob. 2008. Minority language renewal: Gaelic in Nova Scotia, and lessons from abroad. Report for NS Department of Communities, Culture and Heritage. Halifax, NS: Office of Gaelic Affairs.

Dunmore, Stuart. 2017. Immersion education outcomes and the Gaelic community: Identities and language ideologies among Gaelic-medium educated adults in Scotland. Journal of Multilingual and Multicultural Development 38:726-41

Dunmore, Stuart. 2018. New Gaelic speakers, new Gaels? Language ideologies and ethnolinguistic continuity among Gaelic-medium educated adults. In Cassie SmithChristmas, Noel Ó Murchu, Mairéad Moriaty \& Michael Hornsby (eds.), New speakers of minority languages: Linguistic practice and ideology, 23-44. Basingstoke: Palgrave.

Dunmore, Stuart. 2019. Language revitalisation in Gaelic Scotland: Linguistic practice and ideology. Edinburgh: Edinburgh University Press.

Dunmore, Stuart. 2021. 'Emic and essentialist perspectives on Gaelic heritage: New speakers, language policy and cultural identity in Nova Scotia and Scotland', Language in Society 50: 259-81. 
Dunmore, Stuart (forthcoming) New Gaelic Speakers in Nova Scotia and Scotland: Heritage, Motivation and Identity (Edinburgh: Edinburgh University Press).

Dumville, David N. 2002. Ireland and North Britain in the earlier Middle Ages: Contexts for Míniugud Senchasa Fher nAlban. In Colm Ó Baoill \& Nancy R. McGuire (eds) Rannsachadh na Gàidhlig 2000, 185-212. Aberdeen: An Clò Gaidhealach.

Edwards, John R. 2010. Minority languages and group identity: Cases and categories. Amsterdam: John Benjamins.

Edwards, John R. 2013. Bilingualism and multilingualism: Some central concepts. In Tej K. Bhatia and William C. Ritchie (eds.), Handbook of bilingualism and multilingualism, 2nd edn., 5-25. Oxford: Blackwell.

Fishman, Joshua A. 1991. Reversing language shift: Theoretical and empirical foundations of assistance to threatened languages. Clevedon: Multilingual Matters.

Fishman, Joshua A. (ed.). 2001a. Can threatened languages be saved? Reversing language shift revisited: A $21^{\text {st }}$ century perspective. Clevedon: Multilingual Matters.

Fishman, Joshua A. 2001b. From theory to practice (and vice versa): Review, reconsideration, and reiteration. In Joshua Fishman (ed.) Can threatened languages be saved? Reversing language shift revisited: A $21^{\text {st }}$ century perspective, 451-83. Clevedon: Multilingual Matters.

Fishman, Joshua A. 2010. Sociolinguistics: Language and ethnic identity in context. In Joshua A. Fishman \& Ofelia García (eds) Handbook of language and ethnic Identity: Disciplinary and Regional perspectives (Vol. I) $2^{\text {nd }}$ edn. Xxiii-xxxv. Oxford: Oxford University Press.

Fishman, Joshua A. 2013. Language maintenance, language shift, and reversing language shift. In Tej K. Bhatia \& William C. Ritchie (eds.) Handbook of bilingualism and multilingualism, $2^{\text {nd }}$ edn., 466-94. Oxford: Blackwell.

Fishman, Joshua A. \& Ofelia García (eds.). 2010. Handbook of language and ethnic identity: Disciplinary and regional perspectives (Vol. I) $2^{\text {nd }}$ edn. Oxford: Oxford University Press.

Fishman, Joshua A. \& Ofelia García (eds.) 2011. Handbook of language and ethnic identity: The success-failure continuum in language and ethnic identity efforts (Vol. 2), $2^{\text {nd }}$ edn. Oxford: Oxford University Press.

García, Ofelia. 2009. Bilingual education in the $21^{\text {st }}$ Century: A global perspective. Oxford: Blackwell.

Gardner, Robert C. \& Wallace E. Lambert. 1959. Motivational variables in second language acquisition. Canadian Journal of Psychology 13:266-72.

Gardner, Robert C. \& Wallace E. Lambert. 1972. Attitudes and motivation in second language learning. Rowley, MA: Newbury House.

Glaser, Konstanze. 2007. Minority Languages and Cultural Diversity in Europe: Gaelic and Sorbian Perspectives. Clevedon: Multilingual Matters.

Heller, Monica. 2006. Linguistic Minorities and modernity: A sociolinguistic ethnography, $2^{\text {nd }}$ edn. London: Continuum.

Heller, Monica. 2010. Paths to postnationalism: A critical ethnography of language and identity. Oxford: Oxford University Press.

Hornsby, Michael. 2015. Revitalizing Minority Languages: New Speakers of Breton, Yiddish and Lemko. London: Palgrave. 
Hymes, Dell. 1974. Foundations in Sociolinguistics: An Ethnographic Approach. London: Tavistock Publications.

Jaffe, Alexandra. 1999. Ideologies in action: Language politics on Corsica. Berlin: Mouton de Gruyter.

Jaffe, Alexandra. 2007a. Discourses of endangerment: Contexts and consequences of essentializing discourses'. In Alexandre Duchêne \& Monica Heller (eds.) Discourses of endangerment: Ideology and interest in the defence of languages, 57-75. London: Continuum.

Jaffe, Alexandra. 2007b. Minority language movements. In Monica Heller (ed.) Bilingualism: A social approach, 50-95. London: Palgrave Macmillan.

Kennedy, Michael. 2002. Gaelic Nova Scotia: An economic, cultural, and social impact study. Report for Nova Scotia Government. Halifax, NS: Nova Scotia Musuem.

Kroskrity, Paul V. (ed.). 2000. Regimes of language: Ideologies, polities, and identities. Santa Fe, NM: School of American Research Press.

Kroskrity, Paul V. 2004. Language ideologies. In A. Duranti (ed.) A companion to linguistic anthropology. Oxford: Blackwell.

MacEachen, Frances 2008. Am blas againn fhìn: Community Gaelic immersion classes in Nova Scotia - an evaluation of activities in 2006-2007. Report for Office of Gaelic Affairs. Halifax, NS: Office of Gaelic Affairs.

MacIntyre, Peter, Susan Baker \& Heather Sparling. 2017. Heritage passions, heritage convictions and the rooted L2 self: Music and Gaelic language learning in Cape Breton, Nova Scotia. The Modern Language Journal 101:501-516.

MacKinnon, Kenneth. 2001. Gaelic in Canada: Haki and Hekja's inheritance in 'The Land of Promise'. In P. Sture Ureland (ed.). Global Eurolinguistics: European languages in North America - Migration, Maintenance and Death, 19-47. Tübingen: Niemeyer.

MacLean, Raymond. 1978. The Scots: Hector's cargo. In Donald Campbell (ed.). Banked fires: The ethnics of Nova Scotia, 51-72. Port Credit, ON: Scribblers' Press.

Makihara, Miki. 2010. Anthropology. In Joshua A. Fishman, \& Ofelia García (eds.). Handbook of language and ethnic identity: Disciplinary and regional perspectives (Vol. I) $2^{\text {nd }}$ edn, 32-48. Oxford: Oxford University Press.

McEwan-Fujita, Emily. 2008. '9 to 5' Gaelic: Speakers, Context, and Ideology of an Emerging Minority Language Register. In Kendall A. King, Natalie SchillingEstes, Lyn Fogle, Jia Jackie Lou, and Barbara Soukup (eds.). Sustaining Linguistic Diversity: Endangered and Minority Languages and Language Varieties. Washington, DC: Georgetown University Press, pp. 81-93.

McEwan-Fujita, Emily. 2020. Gaelic Revitalization Concepts and Challenges: Collected Essays. Halifax, NS: Bradan Press.

McLeod, Wilson, Bernadette O'Rourke and Stuart Dunmore. 2014. New Speakers of Gaelic in Edinburgh and Glasgow: Soillse research report (Sleat, Isle of Skye: Soillse).

Mertz, Elizabeth. 1982. 'No burden to carry': Cape Breton pragmatics and metapragmatics. Unpublished PhD thesis, Duke University.

Mertz, Elizabeth. 1989. Sociolinguistic creativity. Cape Breton Gaelic's linguistic 'tip'. In Nancy C. Dorian (ed.). Investigating obsolescence. Studies in language contraction and death, 103-116. Cambridge: Cambridge University Press.

Nance, Claire. 2015. 'New' Scottish Gaelic speakers in Glasgow: a phonetic study of language revitalisation. Language in Society 44:553-579 
Nance, Claire, Wilson McLeod, Bernadette O'Rourke and Stuart Dunmore. 2016. Identity, accent aim, and motivation in second language users: new Scottish Gaelic speakers' use of phonetic variation. Journal of Sociolinguistics 20:164-191.

National Records of Scotland. 2013. Statistical Bulletin: 2011 Census - Release 2A $<$ www.scotlandscensus.gov.uk/documents/censusresults/release2a/StatsBulletin2A.pd f> (accessed 26.09.2020).

Nettle, Daniel, and Suzanne Romaine. 2000. Vanishing Voices: The Extinction of the world's languages. Oxford: Oxford University Press.

Ó Baoill, Colm. 2010. A history of Gaelic to 1800. In Moray Watson and Michelle Macleod (eds) Edinburgh Companion to the Gaelic Language, 1-21. Edinburgh: Edinburgh University Press.

Office of Gaelic Affairs. 2018. Our community <https://gaelic.novascotia.ca/ community> (accessed 15.10.2019).

Ó Giollagáin, Conchúr, Gòrdan Camshron, Pàdraig Moireach, Briáin Ó Curnáin, Iain Caimbeul \& Tamás Péterváry 2020. The Gaelic Crisis in the Vernacular Community (Aberdeen: Aberdeen University Press).

Ó hIfearnáin, Tadhg. 2002. Doimhne an dúchais: éagsúlacht san aistriú teanga i gCeap Breatainn na hAlban Nua. Taighde agus teagasc 2:62-91.

Oliver, James. 2002. Young People and Gaelic in Scotland: Identity Dynamics in a changing European Region. Unpublished $\mathrm{PhD}$ thesis, University of Sheffield.

Oliver, James. 2005. Gaelic and identities in Scotland: Contexts and contingencies. Scottish Affairs 51:1-24.

Oliver, James. 2006. Where is Gaelic? Revitalisation, language, culture and identity. In Wilson McLeod (ed.). Revitalising Gaelic in Scotland, 155-68. Edinburgh: Dunedin Academic Press.

O'Rourke, Bernadette \& Fernando Ramallo. 2013. Competing ideologies of linguistic authority amongst new speakers in contemporary Galicia. Language in Society 42: 287-305.

O'Rourke, Bernadette, Joan Pujolar and Fernando Ramallo. 2015. New speakers of minority languages: The challenging opportunity - foreword. International Journal of the Sociology of Language 231:1-20.

Richards, Eric. 2007. Debating the Highland Clearances. Edinburgh: Edinburgh University Press.

Romaine, Suzanne. 2000. Language in society: An introduction to sociolinguistics, $2^{\text {nd }}$ edn. Oxford: Oxford University Press.

Romaine, Suzanne. 2006. Planning for the survival of linguistic diversity. Language Policy 5:44173.

Romaine, Suzanne. 2008. Linguistic diversity, sustainability, and the future of the past.In Kendal King, Natalie Schilling-Estes, Lyn Fogle, Jia Jackie Lou \& Barbara Soukup (eds.). Sustaining Linguistic Diversity Endangered and Minority Languages and Varieties, 721. Washington, DC: Georgetown University Press.

Romaine, Suzanne. 2013. The bilingual and multilingual community. In Tej K. Bhatia \& William C. Ritchie (eds.). The Handbook of Bilingualism and Multilingualism, 2nd edn. 445465. Oxford: Blackwell.

Rosiak, Karolina, forthcoming. The role of language attitudes and ideologies in minority language learning motivation. A case study of Polish migrants' (de)motivation to learn Welsh. Multilingua. 
Saville-Troike, M. 2003. The Ethnography of Communication: An Introduction, $3^{\text {rd }}$ edn. Oxford: Blackwell.

Scottish Government. 2014. Consultation paper on a Gaelic medium education bill Edinburgh: Scottish Government.

Scottish National Party [Scottish Government]. 2021. Scottish National Party Manifesto 2021. Edinburgh: Scottish National Party.

Shaw, John. 1977. Bithidh iad a' moladh na Gàidhlig, ach 'sann anns a' Bheurla. West Highland Free Press, $23^{\text {rd }}$ September.

Silverstein, Michael. 1979, Language Structure and Linguistic Ideology. In Cline, Paul R., William Hanks \& Carol Hofbauer (eds.). The Elements: A parasession on linguistic units and levels, 193-247. Chicago: Chicago Linguistic Society.

Smith-Christmas, Cassandra, Noel Ó Murchadha, Michael Hornsby and Mairead Moriarty (eds.). 2018. New Speakers of Minority Languages: Linguistic Practice and Ideology. London: Palgrave.

Statistics Canada. 2015. National household survey profile: Nova Scotia 2011. Available online: https://www12.statcan.gc.ca/nhs-enm/2011/dp-pd/prof/ (accessed 13.12.2019).

Statistics Canada. 2017. 2011 Census: Detailed mother-tongue - Nova Scotia. Available online: <https://www12.statcan.gc.ca/census-recensement/2011/dp-pd/> (accessed 14.12.2019).

Ushioda, Ema. 2011. Language learning motivation, self and identity: Current theoretical perspectives. Computer Assisted Language Learning 24:199-210.

Watson, Seumas \& Marlene Ivey. 2016. Nàisean cultarach nan Gàidheal: Ath-chruthachadh tìrdhùthchasaich ann an Albainn Nuaidh. In Wilson McLeod, Anja Gunderloch and Rob Dunbar (eds.). Rannsachadh na Gàidhlig 8, 183-194. Edinburgh: Dunedin Academic Press.

Williams, Colin, forthcoming. Language Policy and the New Speaker Challenge. Cambridge: Cambridge University Press.

Withers, Charles W. J. 1984. Gaelic in Scotland 1698-1981: The Geographical History of a Language. Edinburgh: J. Donald. 